\title{
Reduction of post harvest diseases and prolonging the shelf- life of banana through chemical and botanicals
}

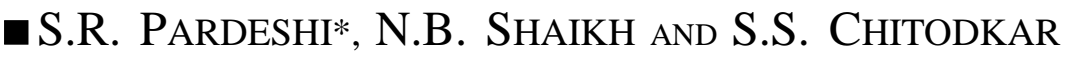 \\ Banana Research Station, JALGAON (M.S.) INDIA \\ *Author for Correspondence \\ Research chronicle : Received : 08.12.2014; Accepted : 31.05.2015
}

\begin{abstract}
SUMMARY :
For reducing the post-harvest losses and extension of shelf-life of banana, the fungicides were found beneficial. The botanicals are also useful to reduce the post harvest losses and to enhance the shelf-life. A study was conducted to find the best method to control post-harvest diseases and extension of shelf-life of banana through chemicals and botanicals. The treatment of dipping fruits in 0.1 per cent carbendanzem was found more effective for control of decay and crown rot. The second best treatment for this purpose was dipping of banana fruits with 50 per cent extract of Solanum torvum. The best treatment dipping the banana fruits in $(0.1 \%)$, respectively against untreated fruits. Post-harvest loss of these varieties was reduced, respectively by 95 per cent and 70 per cent against untreated fruits. Firmness of treated fruits for both varieties was found higher than that of untreated fruits during ripening.
\end{abstract}

KEY WORDS : Shelf-life, Banana, Chemical, Botanical, Post-Harvest

How to cite this paper : Pardeshi, S.R., Shaikh, N.B. and Chitodkar, S.S. (2015). Reduction of post harvest diseases and prolonging the shelf-life of banana through chemical and botanicals. Internat. J. Proc. \& Post Harvest Technol., 6 (1) : 125-127. 